\title{
HUBUNGAN PERAN PERAWAT DAN DIAGNOSA KEPERAWATAN
}

\author{
Fanisa Nur Siregar
}

fanisanursiregar09@gmail.com

\begin{abstract}
Abstrak
Diagnosa keperawatan adalah suatu penilaian klinis yang menggambarkan tentang respons yang diberikan oleh individu, keluarga, atau kelompok terhadap masalah kesehatan atau proses kehidupan aktual ataupun potensial sebagai dasar pemilihan intervensi keperawatan secara tepat untuk menjaga status kesehatan klien. Dalam memberikan asuhan keperawatannya, perawat juga bertanggung jawab dalam memberikan diagnosa keperawatan untuk setiap klien. Peran seorang perawat adalah sebagai pemberi asuhan keperawatan, dengan memperhatikan keadaan kebutuhan dasar manusia. Tujuan dari diagnosa keperawatan ini adalah untuk mengidentifikasi masalah adanya respon klien terhadap status kesehatan, untuk mengidentifikasi faktor penyeab masalah dan untuk mengetahui kemampuan klien untuk mencegah atau menyelesaikan masalah.
\end{abstract}

Kata kunci : diagnosa keperawatan, peran perawat

\section{Latar belakang}

Asuhan keperawatan adalah suatu langkah proses keperawatan dalam memberikan asuhan keperawatan yang terdiri dari lima tahapan yang dimulai dari tahap pengkajian, diagnosa keperawatan, perencanaan keperawatan dan evaluasi (Nursalam, 2008). Perawat dituntut untuk selalu melaksanakan asuhan keperawatan yang benar atau rasional. Dalam memberikan asuhan keperawatannya, perawat juga bertanggung jawab dalam memberikan diagnosa keperawatan untuk setiap klien. Diagnosa keperawatan adalah suatu penilaian klinis yang menggambarkan tentang respons yang diberikan oleh individu, keluarga, atau kelompok terhadap masalah kesehatan atau proses kehidupan aktual ataupun potensial sebagai dasar pemilihan intervensi keperawatan secara tepat untuk menjaga status kesehatan klien.

Diagnosa keperawatan merupakan tahap kedua dalam proses keperawatan setelah perawat melakukan pengkajian. Diagnosa keperawatan juga merupakan langkah yang sangat 
penting dalam proses keperawatan. Dalam memberikan diagnosa keperawatan, perawat perlu berpikir kritis untuk menginterpretasikan data pengkajian dan mengidentifikasi kekuatan serta masalah dari klien. Tujuan dari diagnosa keperawatan ini adalah untuk mengidentifikasi masalah adanya respon klien terhadap status kesehatan, untuk mengidentifikasi faktor penyeab masalah dan untuk mengetahui kemampuan klien untuk mencegah atau menyelesaikan masalah.

Diagnosa keperawatan terdiri dari masalah, penyebab, dan tanda atau gejala yang muncul. Kemudian perawat bekerjasama dengan klien dan petugas kesehatan lain untuk menentukan diagnosa keperawatan, melakukan pengkajian ulang, dan merevisi diagnosa yang telah ditetapkan sebelumnya berdasarkan data terbaru yang diperoleh setelah melakukan pengkajian ulang (Nursalam2007). Semua diagnosa keperawatan harus didukung oleh data- data yang lengkap dan jelas, dimana menurut NANDA diartikan sebagai defenisi karakteristik. Definisi karakteristik tersebut dinamakan tanda dan gejala. Tanda adalah sesuatu yang dapat diobservasi atau dilihat dan gejala adalah sesuatu yang dapat dirasakan oleh seseorang. Untuk mendapatkan diagnosa keperawatan, pada saat pengkajian perawat perlu memperhatikan dan mempertimbangkan proses kesehatan seperti apa yang sedang berlangsung pada klien. Dengan mengidentifikasi perilaku yang dilakukan oleh klien, perawat dapat menilai kemajuan dalam menyelesaikan proses dan menggunakan informasi tersebut untuk merumuskan diagnosa keperawatan.

\section{Metode}

Metode yang digunakan untuk mendapatkan informasi dalam pembuatan jurnal ini adalah menggunakan metode kepustakaan yaitu membaca dan menganalisa jurnal online, e-book, dan karya ilmiah dan sumber lainnya yang tepat, sesuai dan berfokus kepada diagnosa keperawatan. Dengan menggunakan jurnal dan e-book dengan terbitan paling tua tahun 2012.

\section{Hasil}

Menurut Gordon ( 1976 ) Diagnosa keperawatan adalah masalah kesehatan aktual atau potensial dimana perawat, dengan pendidikan dan pengalamannya, mampu dan mempunyai izin untuk mengatasinya. Diagnosa keperawatan adalah suatu penilaian klinis yang menggambarkan tentang respons yang diberikan oleh individu, keluarga, atau kelompok terhadap masalah kesehatan atau proses kehidupan aktual ataupun potensial sebagai dasar pemilihan intervensi 
keperawatan secara tepat untuk menjaga status kesehatan klien. Langkah-langkah dalam menentukan diagnosa keperawatan adalah :

1. Melakukan klasifikasi data. Klasifikasi data adalah kegiatan mengelompokakan data-data klien atau keadaan tertentu tempat klien mengalami permasalahan kesehatan atau keperawatan berdasarkan kriteria permasalahannya. Klasifikasi ini berdasarkan pada kebutuhan dasar manusia yang dikelompokkan dalam data subjektif dan data objektif.

2. Membuat Interpretasi Data, perawat bertugas membuat interpretasi atas data yang sudah dikelompokkan dalam bentuk masalah keperawatan atau masalah kolaboratif.

3. Menentukan Hubungan Sebab Akibat, dari masalah keperawatan yang telah ditentukan kemudian, perawat harus menentukan faktor-faktor yang berhubungan atau faktor risiko yang menjadi kemungkinan penyebab dari masalah yang terjadi. Kemungkinan penyebab harus mengacu pola kelompok data yang sudah ada.

4. Merumuskan Diagnosis Keperawatan, perumusan diagnosis keperawatan yang dibuat didasarkan pada pola identifikasi masalah dan kemungkinan penyebab.

Perawat diharapkan memiliki rentang perhatian yang luas, baik pada klien sakit maupun sehat. Perawat juga harus mampu berpikir kritis dalam menentukan diagnosa keperawatan. Tujuan diagnose keperawatan untuk mengidentifikasi :

a) Masalah dimana adanya respon klien terhadap status kesehatan atau penyakit

b) Faktor-faktor yang menunjang atau menyebabkan suatu masalah (etiologi)

c) Kemampuan klien untuk mencegah atau menyelesaikan masalah.

Perawat berperan sebagai pemberi asuhan keperawatan dengan proses asuhan keperawatan yang meliputi pengkajian, diagnosa keperawatan, perencanaan keperawatan dan evaluasi. Oleh karena itu ketepatan dan keefektifan perawat dalam menentukan ataupun memberi diagnosa keperawatan mampu meningkatkan kinerja perawat dan juga akan meningkatkan kesejahteraan terhadap pasien.

\section{Pembahasan}

Diagnosa keperawatan adalah suatu penilaian klinis yang menggambarkan tentang respons yang diberikan oleh individu, keluarga, atau kelompok terhadap masalah kesehatan atau 
proses kehidupan aktual ataupun potensial sebagai dasar pemilihan intervensi keperawatan secara tepat untuk menjaga status kesehatan klien. North American Nursing Diagnosis Association (NANDA) menyatakan bahwa diagnosis keperawatan adalah keputusan klinik mengenai respon individu (klien dan masyarakat) tentang kesehatan yang aktual atau potensial sebagai dasar seleksi intervensi keperawatan untuk mencapai tujuan asuhan keperawatan sesuai dengan kewenangan perawat.

Diagnosa keperawatan merupakan tahap kedua dalam proses keperawatan setelah perawat melakukan pengkajian. Diagnosa keperawatan juga merupakan salah satu langkah yang sangat penting dalam pemberian proses keperawatan. Didalam diagnosa keperawatan terdapat komponen-komponen penting. Berikut adalah komponen dari diagnosa keperawatan yaitu :

1. Problem (masalah), merupakan sebuah gambaran keadaan klien dimana tindakan keperawatan dapat diberikan. Masalah adalah penyimpangan dari keadaan status normal yang seharusnya tidak terjadi pada seseorang.

2. Etiologi (penyebab), dimana keadaan ini menunjukkan penyebab suatu keadaan atau masalah kesehatan yang memberikan arah kepada terapi keperawatan. Pada komponen ini perawat mengidentifikasi salah satu atau lebih penyebab masalah kesehatan yang mungkin.

3. Sign \& symptom (tanda \& gejala), adalah ciri, tanda atau gejala, yang merupakan informasi yang diperlukan untuk merumuskan diagnosis keperawatan.

Langkah-langkah dalam menegakkan diagnosa keperawatan adalah mengklasifikasi dan menganalisa data, menginterpretasi data, memvalidasi data, dan yang terakhir merumuskan diagnosis keperawatan. Menurut Herdman (2012) diagnosa keperawatan dapat dibedakan menjadi diagnosa keperawatan aktual, resiko, kemungkinan, dan kesejahteraan dan sindrom.

\section{Diagnosa Keperawatan Aktual}

Sebuah diagnosa yang menggambarka keadaan klinis yang telah divalidasi oleh perawat melalui batasan karakteristik tertentu yang diidentifikasi. Diagnosa ini mempunyai empat komponen yaitu : label, definisi, batasan karakteristik, dan faktor yang berhubungan.

2. Diagnosa Keperawatan Risiko 
suatu keputusan klinis tentang individu maupun komunitas lainnya yang sangat rentan terkena masalah yang sama dibandingkan dengan individu maupun komunitas lain dalam situasi yang serupa.

\section{Diagnosa Keperawatan Kemungkinan}

Diagnosa keperawatan kemungkinan adalah suatu diagnosa yang dianggap masih memerlukan data tambahan dengan tujuan masih diperlukan untuk memastikan adanya tanda dan gejala utama adanya faktor resiko.

4. Diagnosa Keperawatan Sejahtera

Diagnosa keperawatan sejahtera adalah ketentuan klinis mengenai individu, kelompok, atau masyarakat dalam transisi dari tingkat kesehatan khusus ke tingkat kesehatan yang lebih baik.

\section{Diagnosa Keperawatan Sindrom}

Diagnosa keperawatan sindrom merupakan kumpilan dari suatu gejala diagmosa keperawata. diagnosa ini terdiri dari beberapa diagnosa keperawatan aktual atau resiko, yang diduga akan muncul karena suatu kejadian tertentu.

Dalam menentukan diagnosa keperawatan berhubungan erat dengan tahap pengkajian. Dimana diagnosa keperawatan ditentukan berdasarkan data yang diperoleh pada saat melakukan pengkajian. Dalam merumuskan diagnosis keperawatan menurut Wilkinson (2007) terdapat beberapa kegiatan yang dilakukan dalam mendiagnosis keperawatan adalah interpretasi dari data

yang ada, kemudian melakukan verifikasi dengan pasien, menentukan label diagnosis keperawatan dan menuliskan diagnosis keperawatan. suatu diagnosa keperawatan juga dapat berupa masalah kesehatan yang bersifat aktual secara klinis jelas atau masalah kesehatan potensial dimana faktor-faktor resiko dapat mengancam kesehatan pada pasien secara umum. Untuk menentukan diagnosa keperawatan, perawat perlu menganalisis data yang diperoleh dari tahap sebelumnya. Adapun langkah-langkahnya yaitu :

1. Membandingkan data terhadap standar(mengidentifikasi petunjuk yang signifikan dari klien)

2. Mengelompokkan petunjuk (menghasilkan hipotesa sementara). Mengelompokkan data ini termasuk membuat kesimpulan tentang data. Disini perawat menginterpretasikan kemungkinan dari petunjuk yang ada. 
3. Mengidentifikasi celah dan ketidakkonsistenan. Analisis data harus mencakup pemeriksaan akhir untuk mengetahui dan memastikan bahwa data tersebut lengkap dan benar.

Penentuan diagnosa keperawatan lebih sulit dan kompleks dibandingkan dengan penetuan diagnose medis. Karena diagnose keperawatn sering berubah-ubah sesuai dengan keadaan pasien sdedangkan diagnose medis merupakan identifikasi kondisi penyakit berdasarkan evaluasi tertentu dari tanda fisik, gejala,riwayat medis klien, hasil pemeriksaan, dan prosedur diagnostic. Peran perawat dapat diartikan sebagai suatu tingkah laku yang diharapkan oleh orang lain terhadap seseorang sesuai dengan kedudukan dalam sistem, dimana dapat dipengaruhi oleh keadaan sosial baik dari profesi perawat maupun dari luar profesi keperawatan yang bersifat konstan(tetap). Salah satu peran seorang perawat adalah sebagai pemberi asuhan keperawatan, dengan memperhatikan keadaan kebutuhan dasar manusia yang dibutuhkan melalui pemberian pelayanan keperawatan dengan menggunakan proses keperawatan dari yang sederhana sampai dengan kompleks. Dimana suatu proses keperawatan terdiri dari lima tahap yang dimulai dari tahap pengkajian, diagnosa keperawatan, perencanaan keperawatan dan evaluasi. Perawat juga sebagai Kolaborator, peran ini dilakukan karena perawat bekerja melalui tim kesehatan yang terdiri dari dokter, fisioterapis, ahli gizi dan lain-lain berupaya mengidentifikasi pelayanan keperawatan yang diperlukan termasuk diskusi atau tukar pendapat dalam penentuan bentuk pelayanan selanjutnya. Dari peran sebagai kolaborator, perawat juga berhar endiskusikan diagnosa keperawatannya dengan tenaga medis lain untuk menentukan hasil akhir. Hubungan peran perawat dengan diagnosa keperawatan adalah seorang perawat mempunyai peran untuk mendiagnosa kliennya sesuai dengan perannya. Sebelum mendiagnosa klien perawat sudah seharusnya sadar akan perannya. Oleh karena itu hubungan peran perawat dan diagnose keperawatan saling berkaitan.

\section{Penutup}

Diagnosa keperawatan adalah suatu bentuk penilaian klinis tentang respons yang diberikan individu, keluarga, atau kelompok terhadap masalah kesehatan atau proses kehidupan aktual maupun potensial sebagai dasar untuk memilih intervensi keperawatan untuk mencapai sebuah hasil yang sesuai dengan status kesehatan seseorang. Peran perawat dalam memberikan diagnosa keperawatan pada klien sangat berhubungan erat. Karena diagnosa keperawatan 
merupakan asuhan keperawatan yang harus didapatkan oleh klien. Sebelum memberikan diagnosa keperawatan perawat harus memahami perannya serta harus menguasai berbagai jenis diagnosa keperawatan. Sehingga perawat mampu membuat keputusan dalam mendiagnosa keadaan kliennya. Dengan digambarkannya langkah-langkah dalam mendiagnosa keperawatan yang baik dan benar, maka dapat mengurangi kesalahan dalam mendiagnosa. Serta perawat dapat menentukan tindakan apa yang diambil selanjutnya.

\section{Daftar pustaka}

Apriyani, H. (2015). Identifikasi Diagnosis Keperawatan Pada Pasien Di Ruang Paru Sebuah Rumah Sakit. Jurnal Keperawatan, Volume XI, No. 1.

Bidjuni , H., \& Rompas, S. (2017). Pengaruh Manajemen Model Asuhan Keperawatan Profesional Tim Terhadap Kualitas Pelayanan Keperawatan Di Bangsal Pria Rsud Datoe Binangkang Kabupaten Bolaang Mongondow . e-Jurnal Keperawatan (e-Kp) Volume 5 , Nomor 2.

Budiono. (2016). KONSEP DASAR KEPERAWATAN. Jakarta: Bumi Medika.

Hermand, T. (2012). Diagnosis Keperawatan Defenisi \& Klasifikasi. Jakarta: EGC.

Kusnadi, E. (2017). Analisis Kelengkapan Dokumentasi Keperawatan di Ruang Rawat Inap Non Intensive Rumah Sakit X . Jurnal Bidang Ilmu Kesehatan Vol. 9, No. 1.

Rachmania, D. (2016). Pengembangan Instrumen Diagnosis \& Intervensi Keperawatan Berbasis Standardized Nursing Language (Nanda-I, Noc, Nic) . Jurnal Ners Vol 11 No 2 , 157-163

Salmawati. (2013). Faktor yang Berhubungan dengan Pelaksanaan Dokumentasi Asuhan Keperawatan di Ruang Perawatan RSUD Labuang Baji Makassar. SKRIPSI-UIN Alauddin Makassar. Makassar: Tidak Dipublikasikan.

Santoso, B. (2012). Buku Saku Diagnosis Keperawatan. Edisi 8. Jakarta: Penerbit Buku Kedokteran EGC. 
Simamora, R., Bukit, E., Purba, J., \& Siahaan, J. (2017). Penguatan Kinerja Perawat dalam pemberian asuhan keperawatan melalui pelatihan ronde keperawatan di rumah sakit royal prima medan. jurnal pengabdian masyarakat, 23(2), 300-304.

Simamora, R. H. (2019). Socialization of Information Technology Utilization and Knowledge of Information System Effectiveness at Hospital Nurses in Medan, North Sumatra. Editorial Preface From the Desk of Managing Editor..., 10(9).

Supratti., A. (2016). Pendokumentasian Standar Asuhan Keperawatan Di Rumah Sakit Umum Daerah Mamuju, Indonesia . Jurnal Kesehatan MANARANG, Volume 2, Nomor 1.

Wulandini, P. (2016). Faktor-Faktor Yang Berhubungan Dengan Pendokumentasian Asuhan Keperawatan Di Rumah Sakit Jiwa . Ners Jurnal Keperawatan ,Volume 12, No.2, 131142) . 